\title{
New species of genus Dipropus Germar, 1839 (Coleoptera: Elateridae: Elaterinae) from Sindh, Pakistan
}

\author{
Shabana Mangi, Waheed Ali Panhwar* and Abdul Manan Shaikh \\ Department of Zoology, Shah Abdul Latif University, Khairpur-Pakistan \\ *Corresponding author's email: waheed.panhwar@salu.edu.pk \\ Citation \\ Shabana Mangi, Waheed Ali Panhwar and Abdul Manan Shaikh. New species of genus Dipropus Germar, 1839 \\ (Coleoptera: Elateridae: Elaterinae) from Sindh, Pakistan. Pure and Applied Biology. Vol. 9, Issue 3, pp2088-2096. \\ http://dx.doi.org/10.19045/bspab.2020.90223
}

\begin{tabular}{llll}
\hline \hline Received: 14/02/2020 & Revised: 27/04/2020 & Accepted: 02/05/2020 & Online First: 18/06/2020 \\
\hline \hline
\end{tabular}

\section{Abstract}

Click beetles are well known due to the unusual click mechanism they possess. These beetles belongs to family Elateridae. During the present study click beetles of genus Dipropus were collected from Mehrabpur (Nausherferoze district) of Sindh, Pakistan from the salinity plain areas from during August 2018 to September 2019. The detail study of genus Dipropus revealed in finding of new species i-e: Dipropus sindhensis sp.nov. Beside this, description of new species along with genitalia, spermetheca, and morphological characters are given.

Keywords: Click; Dipropus; Elateridae; Spermtheca; Pakistan

Introduction

The family Elateridae classified into seventeen subfamilies, in which of them Elaterinae is also subfamily it contains the ten tribes and recognized on the basis of taxonomical characteristics including anterior side of head convex, tapered; frontal carina incompletely reach up to anterior side of frons, and claws on tarsal joint, have not basal setae, brown to dark brown body coloration, 3 sections in legs (tarsomere), antennae eleven sections and mandible has tooth like structure [1-4] . Dipropus genus accommodates into subfamily Elaterinae is one of the most largest genus, it contains the more than 150 species in worldwide represented by South America, North, Central America, Antilles and 30 species were also recorded at Brazil [5-8]. Body brown to dark brown, yellowish longer than wider, elliptical, slightly convex, elytra brown to yellowish, Integument highly punctured, antennomere and legs brown, anterior side of carina black. Pubescence long, light golden to yellow, the tarsomere three sections, and simple claws at tarsal and without setae [9]. The genus Dipropus recorded from the North America, Mesoamerican and difficult to recognize the various species identified the 8 species from the America north of Mexico [10,11].

The current new species of this genus is Dipropus sindhensis nov, sp. has identified this genus on the basis of morphological and genitalial basis including such as body coloration dark brown and yellowish, elongated convex. Body sub-cylindrical longer than broader, covered with densely punctuation in umbilicate in shape, frontal edges widely arcuate, anterior sides of carina lengthened as compared to length of the rostrum, antenna of male, female are serrate, 
with 11 sections, first two sections small with setae, sub-cylindrical; $3^{\text {rd }}$ section serrati form smaller than $4^{\text {th }}$ sections ; no difference between the pubescence of both sex, male specimens (3 to 5 and 6 to10) dissimilar in measurements, wider carina (1 to 4 ) tarsomere shorter, membranous lobes [12] The samples of click beetles were collected from various localities including sim, bank on the sim, under stones, light, humid areas leaf litter, flower heads, light, stagnant water and., live in the soil, sand, or rotten wood, leaf litter, they mostly feed on plant material particularly roots and tubers but few click beetles are also predators hence damage to crops, and Dipropus feed on roots, seeds, tubers and stems of numerous vegetable and crops, the main injury caused is crop stand to loss . Dipropus genus contains the new species Dipropus sindhensis nov, sp. is a new species was first time reported from the Sindh Pakistan.

\section{Materials and methods \\ Place for work}

Present study was done on click beetles were recorded from the Khairpur, Nausherferoz, Hyderabad, Jamshoro, Dadu districts of Sindh Pakistan, taxonomical research was conceded at Dipropus genus reported first time new species Dipropus sindhensis nov, spp. at department of Zoology (Entomology laboratory) at Shah Abdul Latif University Khairpur mirs.

\section{Sampling collection}

Various Samples of click beetles were collected from the different localities of various crops including from wetland (salinity), under stone, wheat, tomato, cotton, vegetables, stored corns, herbs, shrub and light traps etc. and also from light trap method, Dipropus sindhensis nov, sp. was collected bank of sim, manually by hand picking traditional methods and kept into bottles [13] .

\section{Methods of imaging}

Digital images of specimen (adult) were taken with high meji infinity camera $350 \mathrm{k}$ pixel camera fitted on dissecting microscope Kyowa Medilux 20 at herbarium of Shah Abdul Latif University Khairpur mirs were used.

\section{Study area and biogeography}

Dipropus sindhensis was collected from the wetland (salinity) area at Mehrabpur, Mehrabpur is town and union council of district Nausherferoz in the province Sindh of Pakistan. It is located at $27.09 \mathrm{~N}, 68.4 \mathrm{E}$, temperature is $40 \mathrm{c}$, elevation $28 \mathrm{~m}$, and it is lies at the main railway line between the Karachi and Lahore and six link roads from north side (Fig. 1 \& 2).

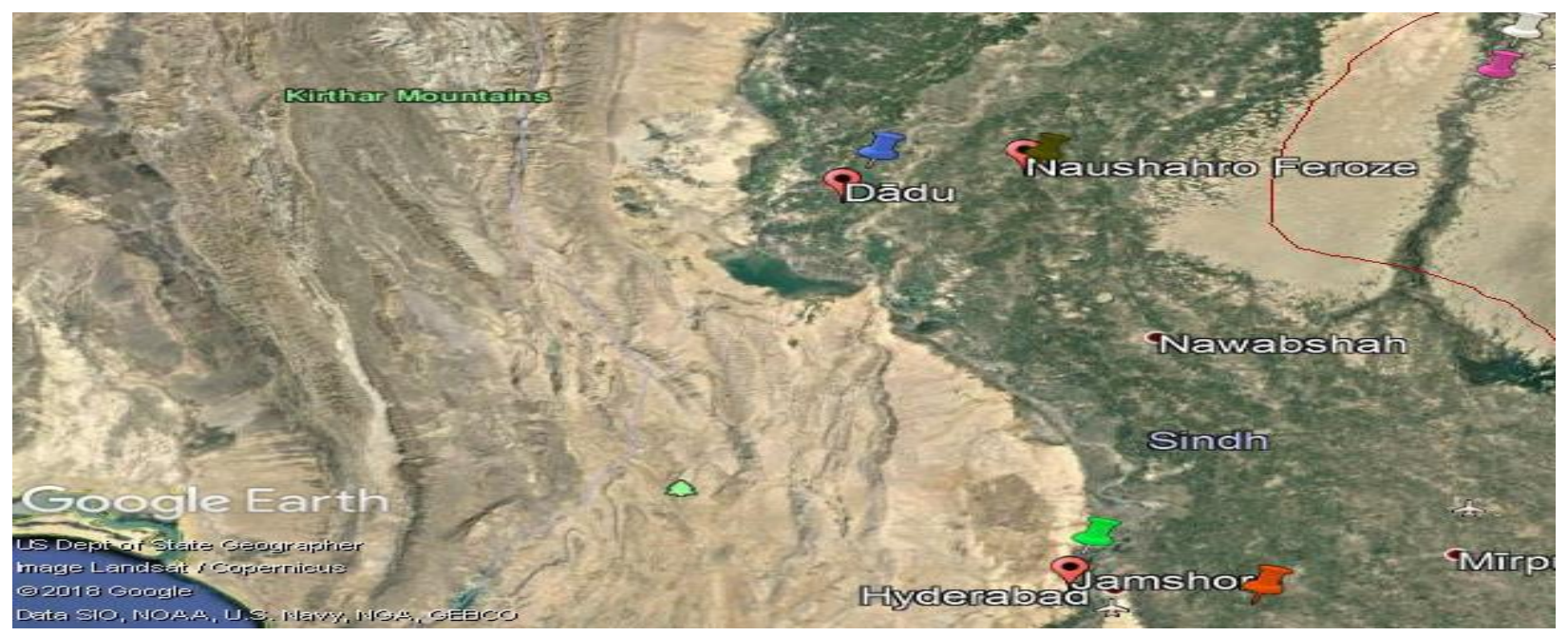

Figure 1. Showing the Map of district Naushahro Feroze 


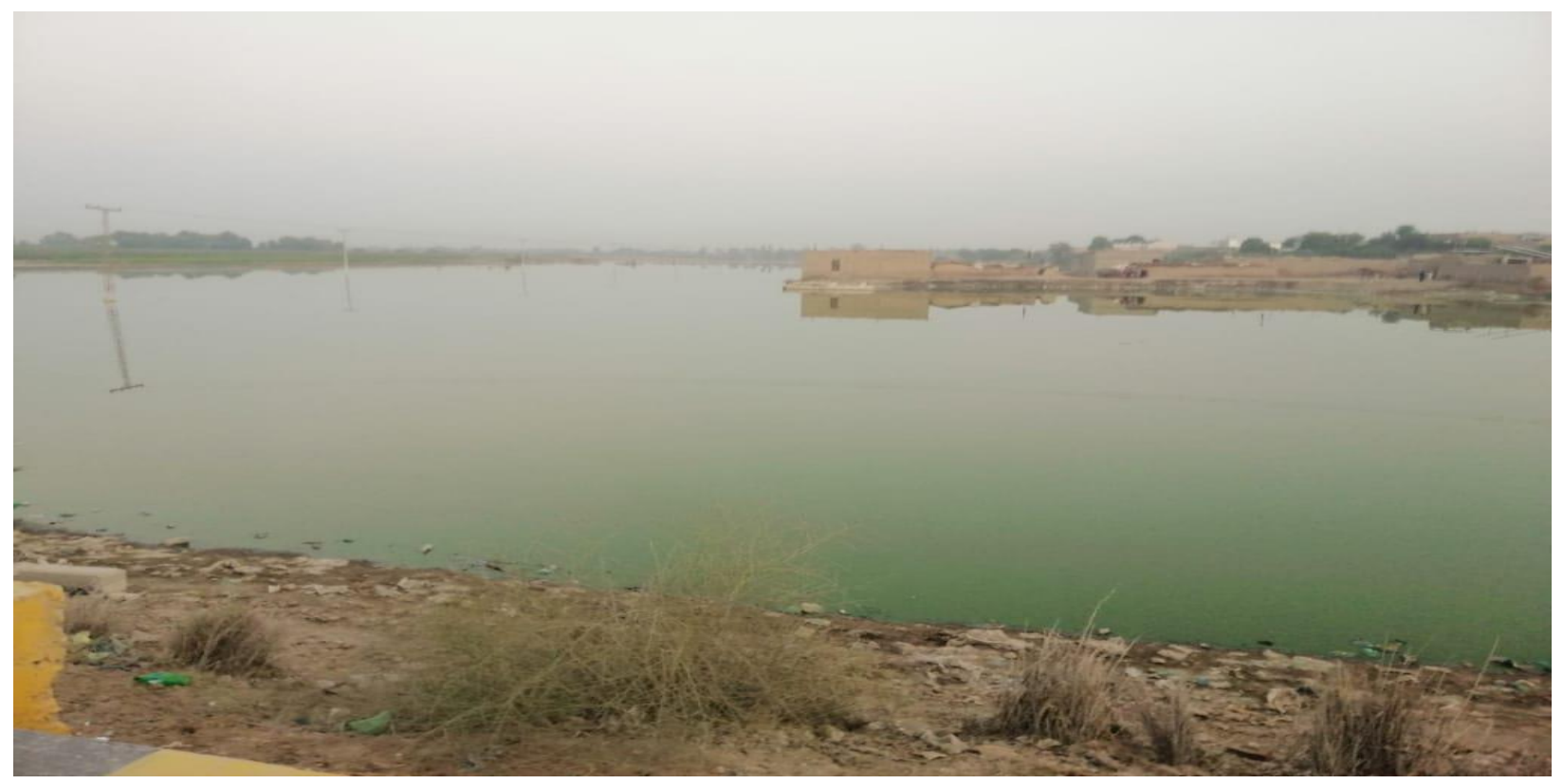

Figure.2. Sampling site of district NaushahroFeroze

\section{Killing and preservation}

Samples were killed into insect killing bottles, which have chloroform for (5 to 10) minutes carefully, draw out from chloroform samples were consciously replaced and well kept up into specific timber insect's boxes. Naphthalene balls were kept for protection from ants and fungus and samples were labelled as per method [14-16].

\section{Identification of beetles}

Collected beetles were identified to the lowest possible taxonomic level with the use of dissecting microscope (KYOWA MEDILUX 20) and references to taxonomic keys and morphological descriptions. Legs, antennae, head, pronotum, and elytra of beetles were dissected where necessary and observed.

\section{Dissection of female genitalia}

The female genitalial part spermtheca and its inner parts inculdings genital coxites, ovipositor, bursa copulatix were boiled into Potassium hydroxide $(\mathrm{KOH})$ for 5-10 minutes, then terminalia genitalia was detached from the abdomen by the help fine forceps and then observed under the dissecting microscope. After that female genitalia was kept in microvials with a drop of glycerin and attached with the respective specimens $[17,18]$.

Measurements and line drawings (Illustrations) of female genitalia

The measurements of full specimens from head to apex, head, pronotum, elytra and full specimen body measurements by the scale [18].

\section{Abbreviation used}

LH: Length of head, WH: Width of head, LP: Length of pronotum, WP: Width of pronotum, LE: Length of elytra, WE: Width of elytra, TL: Total body length.

\section{Results and discussion}

Dipropus sindhensis sp. nov.

\section{Diagnosis}

Genus Dipropus (Germar) described by Candeze (1859), as, (Schwarz, Ischiodontus Candeze (1906b), and [19-21]. This species identified as large size, Black mark present on the frontal area, more space between the humeral angles and abdomen, Yellowish spot on the dorsal surface of pronotum and anterior portions of scutellum yellowish, distinctly punctured on dorsal surface with elongated pubescence. 


\section{Description}

Body of Dipropus sindhensis nov, sp. is longer than wider elliptical, slightly convex, complete body coloration is roughly brown to yellowish with dark infuscate; head dark brown, antennae brownish, Pronotum dark brown, prontal angles black, legs reddish brown Pubescence elongated dark brown yellowish type colorations, black frontal carina, legs reddish brown.

Body elongated convex, head circular distinctly visibly punctuations, yellowish hairs present on the head frontal edges arcuate, carina sides denticated $(0.4 \mathrm{~mm})$, width $(0.7 \mathrm{~mm})$ almost paraclypeus equal to clypeus, antennae 12 section but highly elongated $2^{\text {nd }}$ section cylindrical longer than other section, reaching to tip of hind angles, anterior portion are dark brown in color and posterior sections are light yellowish in color. Pronotum length $(1 \mathrm{~mm})$, width $(2 \mathrm{~mm})$ dorsal surface convex wider than longer, lateral margins convex, lateral edges carinate reaching up to anterior humeral margin; hind edges slightly pointed, concave, deep punctuations on the pronotum, slightly space between the punctuations, punctuation are oval elongated flagellated yellowish large round in shape, humeral angles pointed, tips black slightly concave, more space between the humeral angles and abdomen.

Elytra $(1.6 \mathrm{~mm})$, width $(0.2 \mathrm{~mm})$, convex plane, anterior side concave, crudely punctured, yellowish hairs present on the legs. Striae shallowly concave; apices separate, tarsomere have three joints, thin ventral membranous lobe .Total body length $(3 \mathrm{~mm})$. Female genitalia spermathecal elongated, heart shaped at its base, ovipositor bifurcate.

\section{Morphometry (mm)}

$\mathrm{LH}=0.4, \mathrm{WH}, 0.7, \mathrm{LP}=1, \mathrm{WP}, 2, \mathrm{LE}=1.6$, WE, $0.2, \mathrm{TL}=3$

\section{Type material}

Holotype female was reported from the wetland (salinity) area at Mehrabpur.

\section{Etymology}

The name of new species is derived from Sindh Province, where the species was collected.

\section{Comments:}

Dipropus sindhensis nov, sp. resemble to Conderus methinesis but it can be recognized on the basis of black mark present on the frontal area, more space between the humeral angles and abdomen, yellowish spot on the dorsal surface of pronotum and anterior portions of scutellum yellowish, distinctly punctured on dorsal surface with elongated pubescence [22, 23].

Remarks on Ecology of Dipropus sindhensis nov, sp.

During surveys, specimens were collected from the near water sources, hand picking method was used, they were found from the wetland (salinity) area at Mehrabpur taluka of district Nausherferoze, temperate, humid areas, in summer season high temperature, specimens of Dipropus sindhensis nov, sp. were chewing and sucking type of insects.

\section{Discussion}

The Current study of 9 species of 5 genera were belonging to Agrypninae, Cardiophorinae and Elaterinae subfamilies. The names of those species were given below, Conoderus methiensis Platia (2016), Agriotes lineatus Linaneus (1767), Agriotes duhokensis Platia (2013), Agriotes sameki Platia (2003), Aptopus opata Johnson (2017), Dipropus sindhensis sp.nov, Agrypnus baghensis Akhtar (2014), Agrypnus piger Candeze (1889), Agrypnus argentosquamosus Vatsand Karhyap (1992), study on taxonomy and biogeography of click beetles from certain areas the Khairpur, Hyderabad, Nausherferoz, Sukkur, Dadu, Larakana (Sindh) province, present study was first time study on click beetles its collection and identification reported from Sindh Pakistan $[5,10,29,30]$. Current genus Dipropus globally distributed. The first time new genus described in Sindh as well as in 
Pakistan including Dipropus was reported by Germar, (1839) with type of first time new species Dipropus sindhensis and still not reported this genus and with type of species, but huge work has been done in the oriental and Coahuila, Mexico, de Madre de Dios, Perú, eastern United States, west-central North America and Brazil region. A large number of species of genus Dipropus were reported from the different location at worldwide, Dipropus rufulus Johnson (2016) were reported from the southern Mexico, tropical lowlands and lower montane areas of coastal areas.

Dipropus amarakaeri, Johnson (2018), dorsal surface deeply infuscate, brown yellow rough humeral lines (vittae) pale gold to whitish color of elytra with vague to distinct brown-yellow to dull brick red color (testaecus) discal vittae, legs ad antennae are burnet. Frontal margin bright black and golden to yellow elongated pubescence reported from the Madre de Dios, Peru.

Dipropus losamigos Johnson (2018), collected from Madre de Dios, Peru, head circular with highly puncuation, frontal edges arcuate, carina beaded, elongated antennae, tip of $8^{\text {th }}$ section of antennae up to tip of humeral hind angle; $2^{\text {nd }}$ section subglobular, $3^{\text {rd }}$ section triangular, basal piece of aedeagus subquadrate, middle lobe thin, pointed at tip; arrow paramere lateral spine and tip slightly sclerotized.

Dipropus tequesta Johnson (2018), Integument brown to dark brown, venter moderately pale, antennae dull red, Pubescence slightly pale, paramere tip sagittate, middle lobe, concave, obtuse at tip described from eastern United States. Dipropus soleatus (Say) identified on the taxonomical characteristics body longer than wider, membrane among the tarsal erected from the eastern United States.

Dipropus asper (LeConte), 1890, aedeagus basically identical, powerful spines on tarsomere tarsal pads membranous isolated from each other with sclerotized setae, highly narrow punctuation on head, eyes in female smaller than male antennae small ist section long, $2^{\text {nd }}$ and $11^{\text {th }}$ section almost equal rounded collected from the eastern United States [22-24].

Dipropus pericu pronotum wider than longer, slightly convex, hind angles moderately convex at base, small upper carina, Striae smooth rounded punctuation, space convex, flat apically. Dipropus reinae lines of elytra have circular punctuation, legs concolorous, body castaneous antennae infuscate, rufobrunneous legs and antennae, small [25]. Dipropus Sonora Johnson, P (2016). Body dark black over all, brownish black antennae, antennae slightly elongated reaching upto elytra, 8sections antennae reaching up to hind angle, pronotum wider than longer, scutellum small, densely punctuation on whole body, strongly carinate at hind angle, strongly arcuate.

Dipropus sus (Candèze) Johnson (2017), body longer than wider, black to dark black, body coloration to piceocastaneous; pubescence chalceous, antenna longer reaching upto femora, 8 section of antennae reaching upto tip of hind angle, aedeagus longer than wider, parameres rounded. Dipropus warneri, antennae 8 sections elongated getting upto elytra, pronotum moderately longer than wider, quadrilateral shape, lateral edges toughly, carinate, dorsal surface covered with spotted punctuation umbilicate and convex hind angles, lines separated on elytra and convex, elongated aedeagus at basal piece, paramere longer than wider, reported from the united states, Mexico, Chihuahua and Texas [26, 27].

Dipropus yaqui, frons of head and vertex have a punctuations, umbilicate in shape, frons concave, Compound eyes elongated, 8 antennomere passing upto hind angle, 3 and 10 antennomere slightly serrate, intervals of elytra convex, scutellum small, pronotum, covered with umbilicate punctuations, 
aedeagus longer than wider, parameres truncated. Dipropus ferreus (LeConte), Body longer than wider, ferruginotestaceous to piceocastaneous, Pubescence dark brown, antenna slightly small reaching to meta femoral nick; United States, Sonora, Mexico, Arizona and Santa Cruz, Baja California [28, 29].

Dipropus simplex LeConte (1890), Body chestnut, antennae brownish, elongated, reaching up to anterior sides abdominal have a porous, 8 antennal sections reaching upto tip of pronotum wider than longer, 0.54 total measurments of basal piece of aedeagus, 0.43 total length of paramere Missouri, Michigan, Delaware, Dipropus soleatus (Say) Body elongated than wider, legs concolorous to body, castaneous to piceocastaneous, antennae brownish to infuscate. Antennae median in length, 9 section of antennae reaching tip of hind angle, pronotum wider than longer. 0.55 total length of aedeagus with basal piece, 0.46 total length, paramere 0.35 total length, body form moderately robust; antenna small, reaching tip of pronotal hind angle, Mississippi and Missouri [30].

Dipropus brasilianus (Germar), larva have a smaller punctuations, tergite A9 with tubercles, lines on abdominal have striate and parallel" and Dicrepidius larva as: "A9 tergite with tubercles longer than punctuation, Striae of abdominal striate have bended, reported from the Brazil [31]. Current species diagnosis on the taxonomical characteristics represented by Black mark present on the frontal area, more space between the humeral angles and abdomen, yellowish spot on the dorsal surface of pronotum, anterior portions of scutellum yellowish, antennae brownish antennae 12 section but highly elongated $2^{\text {nd }}$ section cylindrical longer than other section, dark brown and yellowish, Paraclypeus almost equal to clypeus elongated convex. Head dark brown circular, pronotum dark brown convex wider than longer, lateral margins convex, deep punctuations on the pronotum, Legs reddish brown. Punctuation are oval elongated flagellated yellowish large round in shape. Humeral angles pointed, tips black slightly concave. Elytra convex plane, anterior side concave, yellowish hairs present on the head and legs and therefore current study as new species added to science reported from Sindh, Pakistan (Table $1 \&$ Fig. 3 A-F).

Table 1. Showing the Genitalial characters, collecting month and collecting locality of species Dipropus sindhensis nov, sp.

\begin{tabular}{|c|c|}
\hline Characteristics & Dipropus sindhensis. nov, sp. \\
\hline Spermatheca elongated & base, ovipositor bifurcate \\
\hline Spermatheca oval or heart shaped & Two spermathecal duct elongated \\
\hline Collecting month & June \\
\hline Collecting locality & Mehrabpur, Nausherferoz Sindh Pakistan \\
\hline
\end{tabular}




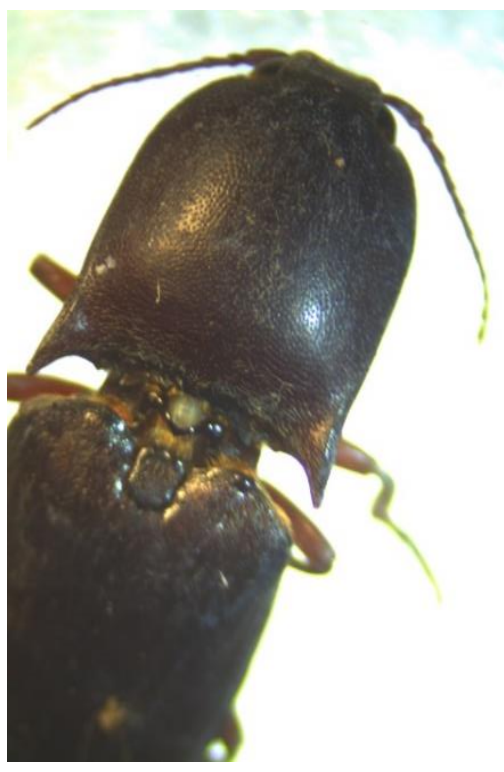

A. head dorsal view

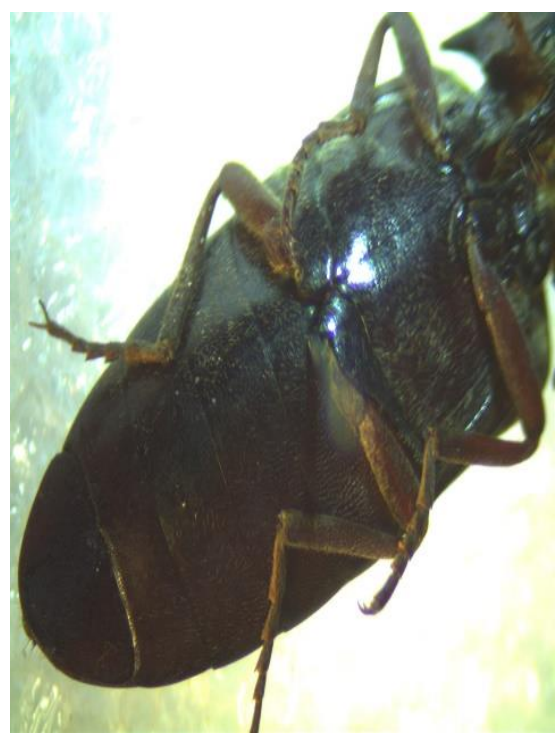

D. Abdomen ventral view

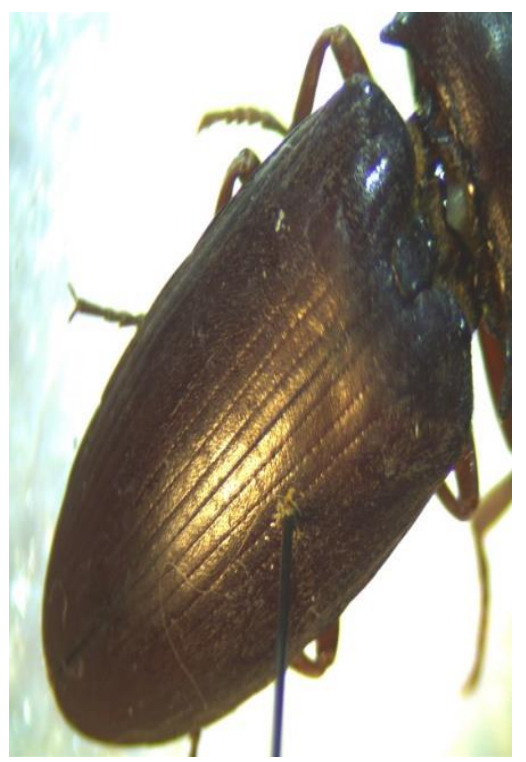

B. Abdomen dorsal view

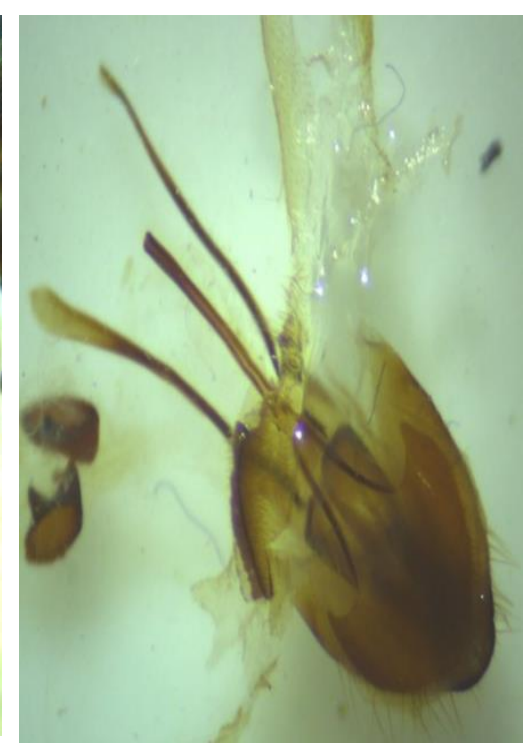

E. Female genitalia spermatheca dorsal view

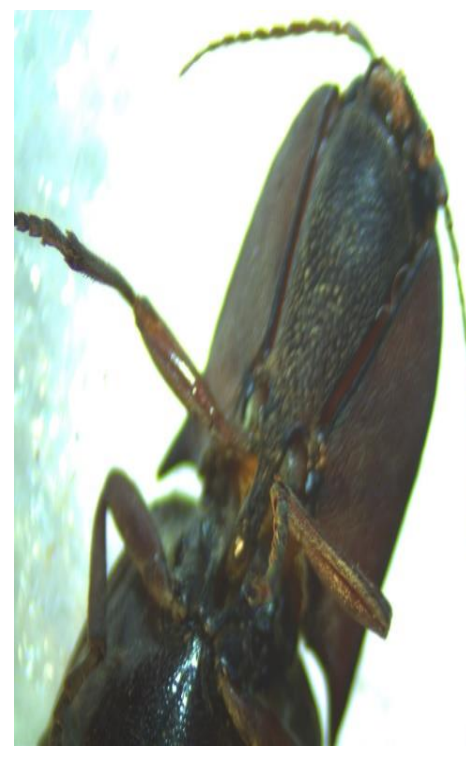

C. head ventral view

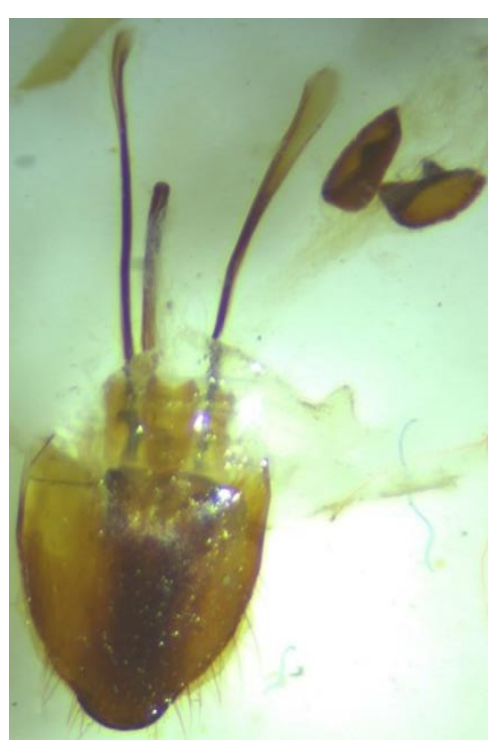

F. Female genitalia spermatheca ventral view

Figure 3(A-F). Showing the digital images along with genitalia

\section{Conclusion}

It is concluded from the present study that geographical features of the Naushahroferoze are diverse and is suitable for the diversity of insects including elaterids beetles. If more surveys will be carried that may lead to more diversity of these beetles.

\section{Authors' contributions}

Conceived and designed the experiments: $\mathrm{S}$ Mangi, WA Panhwar \& AM Shaikh, Performed the experiments: S Mangi, 
Analyzed the data: S Mangi, WA Panhwar \& AM Shaikh, Contributed materials/ analysis/ tools: S Mangi, WA Panhwar \& AM Shaikh. Wrote the paper: S Mangi.

\section{Acknowledgments}

The authors are highly thankful to the anonymous reviewers for their valuable suggestions.

\section{References}

1. Casari SA (2013). New genera of Dicrepidiini from the Neotropical Region (Coleoptera, Elateridae, Elaterinae, Ampedini). Zool 3721(2): 143-156.

2. Schwarz O (1906b-1907). Coleoptera, Fam. Elateridae. Genera Insectorum 46B: 1-224 [1906], 225-370 [1907]. V. Verteneuil \& L. Desmeet, Bruxelles, Belgium.

3. Champion GC (1895). Fam. Elateridae, p. 297-440. In: FD Godman and O Salvin (eds.). Biologia CentraliAmericana, Insecta, Coleoptera, Vol 3, part 1, Serricornia. RH Porter; London, UK 15(690): 27.

4. Akhter K (2005). Preservative treatment of rubber wood (Hevea brasiliensis) to increase its service life. In The international research group on wood protection, 6th annual meeting, Bangalore, India. 1-10.

5. Akhter K \& Ahmed Z (2011). Notes on species of Cardiophorinae (Candèze, 1860) from Pakistan with description of a new species (Coleoptera Elateridae) and new records. Pak J of Zool 43 (3): 477-481.

6. Germar EF (1839). Ueber die Elateriden mit häutigen Anhängen der Tarsengleider. Zeits T Für Die Entomol (1): 197-236.

7. Johnson PJ (2016). Five new species of Dipropus Germar (Coleoptera: Elateridae) from west-central North America, and a lectotype designation for
Elater soleatus Say. Insec Mun 0523: 127.

8. LeConte JL (1890). Additional descriptions of new species. pp 373-434. In: E. A. Schwarz. The Coleoptera of Florida. Proceed of the Amer Philosop Soci., (17): 353-472.

9. LeConte JL (1863). List of the Coleoptera of North America, Part I. Smith Miscell Collec 6(140): 1-78.

10. Akhter AM, Kabalak, MR \& Ahmed Z (2014). Contributions to Agrypninae (Coleoptera: Elateridae) fauna of Pakistan with four new species three new records. Turk Jour of Entomo 38(2): 113123.

11. Bouchard PIB \& Smith (2011). Familygroup names in Coleoptera (Insecta). Zookey 88: 1-972.

12. Blackwelder RE (1944). Checklist of the coleopterons' insects of Mexico, Central America, The West Indies, and South America. Unit Stat Nat Mus Bull 185(2): 189-341.

13. Casari SA (2008). A phylogenetic study of the subtribe Dicrepidiina (Elateridae, Elaterinae, Ampedini). Revis Brasil de Entom 52(2): 182-260.

14. Clark HL (1963). A revision of the United States elaterid beetles of the Tribe Dicrepidiini (Coleoptera: Elateridae). Unpubl. Ph.D. dissertation, Catholic University of America; Washington, DC (52): 5.

15. Candèze ECA (1859). Monographie des Élatérides, tome second. Mémo de la Société Royale Des Sci de Liè (14): 1543.

16. Johnson PJ \& Blaine AM (2017). A new species of Dipropus Germar (Coleoptera: Elateridae) from Florida, with taxonomic and morphological notes and a new key to the species of the eastern United States Insec Mun 0566: 1-7.

17. Claus W \& David (2012). Click beetles from the Maltese Islands (Coleoptera, 
Elateridae). Bull of the entom Soc of Mal 5: 97-103.

18. Schwarz O (1904). Neue Elateriden aus Süd-Amerika. Entomologische Zeitschrift, 1904(Heft 1): 49-80. Schwarz O. 1906a. Neue Elateriden aus Amerika. Deuts Entomol Zeitsch 1906(1): 97-158.

19. Akhter (2014). Contributions to Agrypninae (Coleoptera: Elateridae) fauna of Pakistan with four new species three new records. Turk $J$ of Entom 38(2): 113-123.

20. Panhwar WA (2018). Biodiversity of Caelifera (Orthoptera) from Gorakh Hill Station, Dadu Sindh Pakistan. J of Entom and Zool Stud 6(3): 372-378.

21. Casari SA (2017). A new genus and two new species of Dicrepidiina (Coleoptera: Elateridae: Elaterinae: Ampedini) from Brazil, with a revised key to the genera of the subtribe. The Coleopt Bull 71(4): 753-763.

22. Johnson PJ (2018). New species of Elateridae (Coleoptera) from Sonora, Mexico, with new country and state records, new taxonomic changes and a classificatory checklist. Dugesiana 25(1): 11-31.

23. Clark HL (1963). A revision of the United States elaterid beetles of the tribe Dicrepidiini (Coleoptera: Elateridae). Unpubl. Ph.D. dissertation, Catholic University of America; Washington, DC 52: 5 .
24. Johnson PJ (2017). A new species of Dodecacius Schwarz (Coleoptera: Elateridae from Madre de Dios, Peru / Una nueva especie de Dodecacius Schwarz (Coleoptera: Elateridae) de Madre de Dios, Perú. Revisit Peru de Biol 24(3): 243-248.

25. LeConte JL (1853). Revision of the Elateridae of the United States. Trans of the Amer Philosoph Soc 10: 405-508.

26. Panhwar WA (2018). Biodiversity of Caelifera (Orthoptera) from Gorakh Hill Station, Dadu Sindh Pakistan. J of Entom and Zool Stud 6(3): 372-378.

27. Schenkling S (1928). Throscidae. Coleopterorum Catalogus auspiciis et auxilio W Junk, 11, Pars 101: 1-26.

28. Schwarz O (1906a). Neue Elateriden aus Amerika. Deuts Entom Zeitschr. 1906(Heft 1): 97-158.

29. Akhter AM, Platia, Rizvi AS \& Ahmed Z (2012). Notes on species of the genus Meristhus Candèze, (1857) (Coleoptera: Elateridae: Agrypninae) from Pakistan with a description of a new species. Pak J of Zool 44(1): 67-70.

30. Rafi (2010). Faunistics of tiger beetles (Coleoptera: Cicindelidae) from Pakistan. J of Insec Sci 10(116): 1-23.

31. Platia \& Zubair (2016). Contribution to the fauna of click beetles (Coleoptera: Elateridae) from Pakistan Arquiv Entom 16: 3-28. 